\title{
Szanse i trudności w rozwiązywaniu konfliktów rodzinnych przy wsparciu mediatora
}

\section{Wprowadzenie}

Jednym ze sposobów rozwiązywania konfliktów rodzinnych są mediacje. W ich trakcie członkowie rodziny mogą, przy wsparciu bezstronnego i neutralnego mediatora, znaleźć korzystne dla wszystkich rozwiązanie sporu. Mediacja należy do ugodowych sposobów rozwiązywania konfliktów, a warunki porozumienia są w niej wypracowywane wspólnie przez wszystkich jej uczestników. To do nich należy każda decyzja, ale równocześnie to na nich spoczywa odpowiedzialność za wszystkie ustalenia. Mediacja jest dobrowolna, co oznacza, że w każdej chwili członkowie rodziny mogą od niej odstąpić. Dla stron konfliktu mediacja jest szansą nie tylko na rozwiązanie sporu, ale przede wszystkim daje możliwość zachowania relacji rodzinnych. Skupia się bowiem na możliwościach, które przynoszą obopólne korzyści, 
jednak decyzje dotyczące warunków porozumienia podejmowane są samodzielnie przez każdą ze stron uczestniczącą w mediacji.

Ważną rolę w procesie wzajemnych uzgodnień pełni mediator. Jest on osobą niezaangażowaną w spór i nie ma żadnej mocy decyzyjnej, pozostaje bezstronny wobec osób biorących udział w mediacji oraz neutralny wobec przedmiotu ich sporu. Jego pomoc polega na wsparciu rodziny w procesie wzajemnej komunikacji. Mediator umożliwia konstruktywną rozmowę, dzięki której możliwe jest wypracowanie porozumienia. Nie jest to łatwe zadanie, gdyż członkowie rodziny najczęściej już od dawna używają nieefektywnej komunikacji - nie chcąc, nie potrafiąc lub nie mogąc się ze sobą porozumieć, co dodatkowo eskaluje konflikt. Tym samym mediacja może stać się przyczynkiem do zmiany dotychczasowych wzorców porozumiewania się, zwiększyć otwartość na wzajemne potrzeby i interesy czy wreszcie przyczynić się do zmiany w podejściu do konfliktu.

\section{Przestrzeń dla mediacji i negocjacji rodzinnych}

W ujęciu ogólnym mediacja definiowana jest jako dobrowolna i poufna metoda rozwiązywania sporu, w której strony konfliktu przy pomocy bezstronnego i neutralnego mediatora samodzielnie dochodzą do porozumienia ${ }^{1}$. Christopher Moore nazywa ją jedną z odmian wsparcia udzielanego przez osoby trzecie przy dobrowolnym rozwiązywaniu sporów ${ }^{2}$. Anna Kalisz wskazuje, iż mediacje to „negocjacje we troje”, w których każda ze stron przedstawia swoje stanowisko oraz własną propozycję rozwiązania sporu, po czym obie strony, przy wsparciu mediatora, dążą do wypracowania wzajemnie satysfakcjonującego porozumienia ${ }^{3}$. Jedną $z$ odmian mediacji jest mediacja rodzinna, w której biorą udział członkowie danej rodziny. Z praktyki mediacyjnej wynika, że konflikty rodzinne związane są najczęściej

\footnotetext{
1 Ministerstwo Sprawiedliwości, Informacja o postępowaniu mediacyjnym $w$ sprawach rodzinnych, o rozwód i separację, s. 1, www.mediacja.gov.pl/files/doc/informacja-o-mediacji-rodzinnej.pdf (21.05.2020).

2 Ch. W. Moore, Mediacje. Praktyczne strategie rozwiązywania konfliktów, tłum. M. Zieliński, A. Cybulko, Warszawa 2009, s. 11.

3 A. Kalisz, Mediacja jako forma dialogu w stosowaniu prawa, Warszawa 2016, s. 93.
} 
z rozwodem małżonków, podziałem majątku, alimentami i opieką nad dziećmi ${ }^{4}$. Z danych Ministerstwa Sprawiedliwości wynika, że w trakcie postępowania mediacyjnego przedmiotem wzajemnych uzgodnień są głównie kwestie dotyczące wysokości alimentów, kontaktów z dzieckiem, miejsca zamieszkania małoletniego czy sposobu wykonywania władzy rodzicielskiej ${ }^{5}$.

Jak wskazuje Christopher Moore, mediator może zostać włączony do mediacji jako trzecia strona w sytuacji, gdy strony doświadczają gwałtownych emocji utrudniających porozumienie, mają trudności z samodzielną wzajemną komunikacją, pojawiają się między nimi bariery w postaci m.in. stereotypów, błędów w spostrzeganiu, niezgodności co do różnych faktów, sprzeczności interesów czy różnic wartości. Mediator może być pomocy w sytuacji, gdy stronom trudno jest rozpocząć negocjacje lub są w impasie, wsparcie może dotyczyć także samej procedury negocjacyjnej ${ }^{6}$. Autor ten podkreśla, że aby mediacja mogła w ogóle dojść do skutku, niezbędne jest rozpoczęcie przez strony rozmów lub negocjacji ${ }^{7}$. Zwraca uwagę na powiązanie negocjacji i mediacji, wskazując iż „mediacja to przede wszystkim dialog lub negocjacje $z$ udziałem trzeciej strony. Mediacja jest przedłużeniem procedury negocjacyjnej, jako że wiąże się z nadaniem rokowaniom nowego formatu oraz korzystaniem z usług mediatora, który wnosi do interakcji spierających się stron nową jakość i dynamikę"8.

Mediacja bazuje na dobrej wierze uczestników, która przejawia się przystąpieniem do niej z dobrymi intencjami, w otwartości na dialog z drugą osobą oraz gotowością do zawarcia ugody ${ }^{9}$. Brak wiary w osiągnięcie porozumienia na drodze dialogu stoi na przeszkodzie mediacji i wypacza jej

$4 \quad$ J. Szada-Borzyszkowska, Mediacje $w$ rodzinie - możliwość pokojowego rozwiązania konfliktu, w: Wyzwania współczesnego dzieciństwa i rodzicielstwa. Praca socjalna w perspektywie działań wychowawczych, red. J. Szymanowska, Toruń 2014, s. 286.

5 Ministerstwo Sprawiedliwości, Mediacje rodzinne w latach 2006-2018 i w I półroczu 2019 r. Postępowania $w$ sprawach rodzinnych $w$ sądach powszechnych zakończone $w$ wyniku postępowania mediacyjnego w latach 2006-2017, www.isws.ms.gov.pl/pl/baza-statystyczna/ opracowania-wieloletnie/ (19.05.2020). W 2017 roku ugodą zakończyło się 3887 postępowań mediacyjnych, z czego w 2092 ugodach ustalono wysokość alimentów, w 1055 - kontakty z dzieckiem, w 158 - miejsce zamieszkania dziecka, w 137 - sposób wykonywania władzy rodzicielskiej, w 5 - sprawy w trybie Konwencji haskiej z 1980 roku dotyczącej uprowadzenia, w innych sprawach rodzinnych zawarto 440 ugód.

Ch. W. Moore, Mediacje, dz. cyt., s. 28-29.

Ch. W. Moore, Mediacje, dz. cyt., s. 31.

Ch. W. Moore, Mediacje, dz. cyt., s. 31.

9 A. Kalisz, Mediacja jako forma dialogu w stosowaniu prawa, dz. cyt., s. 105. 
ideę. Niezwykle ważna jest także świadomość, że to właśnie do stron konfliktu należy każda decyzja i że to one - a nie mediator - są odpowiedzialne za wszystkie ustalenia i ich realizację. Rolą mediatora jest bowiem wsparcie stron w procesie komunikacji, a nie narzucanie własnego rozwiązania. To tzw. zasada autonomii konfliktu, która kładzie nacisk na to, że konflikt należy do stron i to one same, bez żadnego nacisku zewnętrznego, podejmują decyzję o sposobie jego zakończenia ${ }^{10}$. Duże znaczenie ma tutaj także zasada wzajemnego szacunku, której podstawą jest uznanie godności każdego z uczestników mediacji oraz wysłuchanie wszystkich stron ${ }^{11}$. Rolą mediatora, wspierającego strony w konstruktywnym porozumiewaniu się, jest stworzenie bezpiecznej i przyjaznej atmosfery sprzyjającej szczerej rozmowie oraz poświęcenie czasu i uwagi sprawom, które są ważne dla uczestników spotkania. Mediator pomaga stronom w sformułowaniu problemów i ich stanowisk, a następnie przeformułowaniu stanowisk na interesy. Pomaga w moderowaniu rozmowy i udziela wsparcia we wzajemnej komunikacji, dbając o zrozumiałość wyrażanych przez siebie i strony treści ${ }^{12}$.

Mediator nie narzuca stronom żadnego rozwiązania, to one same podejmują każdą decyzję. Nie opowiada się też po żadnej ze stron ani nie ocenia uczestników procesu, co przyczynia się do zwiększenia poczucia bezpieczeństwa, pozwala na większą otwartość w wyrażaniu własnego stanowiska, potrzeb i interesów. Sprzyja temu także poufność mediacji oraz jej odformalizowany charakter, przejawiający się elastycznością reguł procedury mediacyjnej ${ }^{13}$.

Mediacja jest dobrowolna. Z jej inicjatywą może wyjść każda ze stron konfliktu, także sąd może skierować daną sprawę do mediacji ${ }^{14}$. W tym

10 J. Szada-Borzyszkowska, J. Śliwa, Od konfliktu do porozumienia - czyli o rozwiązywaniu konfliktów droga mediacji, w: Dydaktyczna refleksja o edukacyjnych priorytetach, red. A. Karpińska, M. Zińczuk, Warszawa 2014, s. 289; A. Kalisz, Mediacja jako forma dialogu w stosowaniu prawa, dz. cyt., s. 106.

11 A. Kalisz, Mediacja jako forma dialogu w stosowaniu prawa, dz. cyt., s. 106-107.

12 A. Cybulko, Komunikacja interpersonalna, w: Mediacje. Teoria i praktyka, red. E. Gmurzyńska, R. Morek, Warszawa 2009, s. 71.

13 A. Kalisz, Mediacja jako forma dialogu w stosowaniu prawa, dz. cyt., s. 107-109.

14 W 2018 roku sądy rejonowe skierowały do mediacji 6933 spraw rodzinnych, w pierwszej połowie 2019 roku liczba spraw skierowanych do mediacji wynosiła 3959. Ministerstwo Sprawiedliwości, Mediacje rodzinne w latach 2006-2018 i w I pótroczu 2019 r. Postępowanie mediacyjne $w$ sprawach rodzinnych $w$ sądach rejonowych $w$ latach 2018 - I pótrocze 2019 r., www.isws.ms.gov.pl/pl/baza-statystyczna/opracowania-wieloletnie/ (19.05.2020). 
drugim przypadku rozpoczęcie procesu poprzedza tzw. spotkanie informacyjne organizowane na terenie sądu lub poza jego budynkiem. Zgodnie z rekomendacjami Społecznej Rady ds. Alternatywnych Metod Rozwiązywania Sporów ma ono ma na celu zapoznanie potencjalnych uczestników mediacji z jej ideą i korzyściami, a także zasadami postępowania mediacyjnego i kosztami mediacji. Zainteresowani mają również możliwość zadawania pytań oraz dostępu do publikacji na temat mediacji. Celem spotkania jest tym samym zachęcenie stron do jej podjęcia ${ }^{15}$.

Anna Kalisz wskazuje na liczne korzyści jednostkowe, które wynikają ze skorzystania z tej metody. Dla jej uczestników, rozwiązujących wspólnie sytuację konfliktową, korzyści te mogą wiązać się z poprawą jakości komunikacji, pozytywnymi relacjami i stworzeniem podstaw do przyszłej efektywnej współpracy, a także zmniejszeniem, choćby częściowym, przyczyn konfliktu. Zaletą mediacji w wymiarze jednostkowym jest także rozwój osobisty każdej ze stron ${ }^{16}$. W przypadku mediacji rodzinnych do jej atutów zaliczyć można: oszczędzenie rodzinie wielu stresów związanych z konfliktem rodzinnym, poczucie odpowiedzialności za wspólnie wypracowane rozwiązanie i satysfakcję z samodzielnie podjętych decyzji. Niewątpliwą zaletą tego procesu jest także to, iż ugodzie mediacyjnej może zostać nadana klauzula wykonalności ${ }^{17}$.

\section{Wsparcie mediatora w procesie rodzinnych uzgodnień}

W sparcie mediatora uwidacznia się w każdym momencie procedury mediacyjnej. Składają się na nią wyodrębnione przez Christophera Moore’a etapy, stanowiące ciąg następujących po sobie działań mediatora w postaci: nawiązania relacji ze stronami sporu, wybierania strategii kierującej procesem mediacji, zbierania i analizowania informacji źródłowych, tworzenia

15 Społeczna Rada ds. Alternatywnych Metod Rozwiązywania Sporów przy Ministrze Sprawiedliwości, Rekomendacja Społecznej Rady ds. Alternatywnych Metod Rozwiązywania Sporów przy Ministrze Sprawiedliwości dotycząca scenariusza spotkania informacyjnego na temat mediacji jako polubownej metody rozwiązywania sporów, Warszawa 28.03.2017 r., www. gov.pl/web/sprawiedliwosc/dokumenty-i-deklaracja-o-stosowaniu-mediacji (21.05.2020).

16 A. Kalisz, Mediacja jako forma dialogu w stosowaniu prawa, dz. cyt., s. 112-113.

17 J. Szada-Borzyszkowska, Mediacje w rodzinie, dz. cyt., s. 285. 
szczegółowego planu mediacji oraz budowania zaufania i współpracy. Po ich przeprowadzeniu można rozpocząć sesję mediacyjną, zdefiniować przedmiot sporu i ustalić plan działania oraz ujawnić ukryte interesy stron. Następnie tworzone są i poddawane ocenie warianty porozumienia, które później stanowią przedmiot ostatecznych negocjacji. Końcowym etapem działań mediatora jest sporządzenie formalnej ugody ${ }^{18}$.

Z punktu widzenia skuteczności mediacji rodzinnej szczególnie ważnym etapem mediacji jest próba odkrycia przez skonfliktowane strony, przy pomocy mediatora, własnych potrzeb i interesów. Z perspektywy poszukiwania wzajemnie satysfakcjonującego rozwiązania w mediacji kluczowe jest odejście od deklarowanych przez strony stanowisk właśnie na rzecz zaspokojenia potrzeb i interesów wszystkich uczestników konfliktu. Jak wskazują Roger Fisher, William Ury i Bruce Patton, odkrycie potrzeb i interesów leżących u podstawy każdego ze stanowisk sprzyja poszukiwaniu rozwiązań integrujących, gdyż z perspektywy negocjacyjnej za przeciwnymi stanowiskami niekoniecznie istnieją wyłącznie interesy konfliktowe, oprócz nich mogą to być także interesy wspólne, jak i możliwe do pogodzenia. Skupienie się zatem na znalezieniu rzeczywistych potrzeb i interesów stron sprzyja skutecznym negocjacjom, bowiem jak piszą autorzy: „gdy rozważasz przeciwne stanowiska, szukając leżących za nimi interesów, często możesz znaleźć inne stanowiska, które zadośćuczynią nie tylko twoim, ale i ich interesom"19. Odkrycie potrzeb i interesów, które leżą u podstawy stanowiska każdej ze stron, sprzyja poszukiwaniu takiego rozwiązania, które zapewniłoby realizację maksimum interesów obu stron. Autorzy wskazują, że do takich potrzeb, a równocześnie interesów należą: bezpieczeństwo, status materialny, uznanie i szacunek, przynależność i akceptacja, kontrola nad własną sytuacją i autonomia decyzyjna ${ }^{20}$.

Christopher Moore wskazuje na trzy kategorie interesów, czyli konkretnych warunków lub korzyści, które muszą być spełnione, aby możliwa była efektywna ugoda. Wśród nich wymienia: a) interesy materialne, związane $\mathrm{z}$ potrzebami, które jednostka ma w związku z takimi dobrami jak np. czas czy pieniądze; b) interesy psychologiczne, związane z relacyjnymi lub

\footnotetext{
18 Ch. W. Moore, Mediacje, dz. cyt., s. 80-81.

19 R. Fisher, W. Ury, B. Patton, Dochodząc do TAK. Negocjowanie bez poddawania się, tłum. R. A. Rządca, Warszawa 2013, s. 72.

20 R. Fisher, W. Ury, B. Patton, Dochodząc do TAK, dz. cyt., s. 57-58, 79.
} 
emocjonalnymi potrzebami osób negocjujących, które powstają w trakcie negocjacji lub w wyniku negocjacji; c) interesy proceduralne, związane z preferencjami w zakresie zasad wypowiedzi i wdrażania rozwiązań. W tej kategorii interesów mieszczą się: możliwość wypowiadania się każdego uczestnika, uporządkowany i terminowy przebieg negocjacji, brak ataków werbalnych, negocjacje, które pozwalają na zaspokojenie wzajemnych interesów stron, a nie tylko jednej strony, stworzenie szczegółowego planu wprowadzania ugody przed osiągnięciem ostatecznego porozumienia oraz stworzenie pisemnego dokumentu lub umowy ${ }^{21}$.

Dostrzeżenie potrzeb i wspólnych interesów stron pozwala im na wyjście poza deklarowane stanowisko. W przypadku mediacji rodzinnej odnalezienie i zaspokojenie interesów wydaje się szczególnie ważne, gdyż tworzy to pozytywny klimat negocjacji i dobre relacje między stronami, te zaś mogą skupić się na wspólnym rozwiązywaniu problemów ${ }^{22}$. W procedurze negocjacyjnej takie podejście odpowiada tzw. negocjacjom opartym na interesach, których celem jest znalezienie rozwiązania satysfakcjonującego obie strony, a nie przynoszącego jednostronne zwycięstwo. Zakończenie negocjacji i ugoda są tutaj skutkiem zaspokojenia konkretnych potrzeb i interesów wszystkich stron. Christopher Moore wskazuje, że punktem wyjścia przy tym podejściu do negocjacji jest „wzajemna edukacja oraz rozwijanie obopólnego zrozumienia dla każdego z interesów stron" 23 . Przeciwieństwem negocjacji opartych o interesy są negocjacje pozycyjne, w których każda ze stron skupia się wyłącznie na własnym stanowisku i własnych interesach ${ }^{24}$. Barierami we współpracy mogą być z kolei: negatywne reakcje i emocje doświadczane przez każdą ze stron, siła, pozycyjne zachowanie i potrzeba rywalizacji stron czy wreszcie brak satysfakcji strony z porozumienia $^{25}$. Przed mediatorem staje zatem zadanie zmiany procedury negocjacyjnej, którą stosują członkowie rodziny - z negocjacji pozycyjnych na negocjacje oparte o interesy ${ }^{26}$, gdyż chęć wspólnego rozwiązania problemu jest punktem wyjścia do rozpoczęcia skutecznych mediacji.

\footnotetext{
21 Ch. W. Moore, Mediacje, dz. cyt., s. 86-87.

22 R. Fisher, W. Ury, B. Patton, Dochodzac do TAK, dz. cyt., s. 58.

23 Ch. W. Moore, Mediacje, dz. cyt., s. 88.

24 Ch. W. Moore, Mediacje, dz. cyt., s. 85.

25 W. Ury, Odchodzac od NIE. Negocjacje od konfrontacji do kooperacji, tłum. R. A. Robert, Warszawa 1995, s. 27-29.

26 Ch. W. Moore, Mediacje, dz. cyt., s. 88.
} 
Aby usprawnić komunikację między stronami, mediator może podejmować różne działania o charakterze zapobiegawczym i interwencyjnym. Pierwsze $\mathrm{z}$ nich rozpoczynają się, zanim strony mediacji wejdą w interakcję, a ich celem jest zapobiegnięcie przez mediatora angażowania się stron w nieskuteczną komunikację. Z kolei działania interwencyjne mają wymiar reaktywny i są podejmowane przez mediatora w odpowiedzi na toczącą się między stronami, po rozpoczęciu negocjacji, bezproduktywną komunikację $^{27}$. Działania mediatora uzależnione są tutaj od wielu czynników, wśród których Christopher Moore wyróżnia: poziom rozwoju konfliktu i moment, w którym mediator przystępuje do konfliktu, zdolność stron do rozwiązania własnego sporu, balans sił pomiędzy stronami, stosowane przez strony procedury negocjacyjne, poziom skomplikowania kwestii spornych oraz koncentrację na ustalonym przez mediatora i strony obszarze zainteresowań, którymi mogą być kwestie merytoryczne, procedura mediacyjna bądź relacje ${ }^{28}$.

Nie zawsze jednak wsparcie mediatora w rozwiązywaniu konfliktów jest odpowiednią do potrzeb i skuteczną formą pomocy rodzinie uwikłanej w konflikt. Skomplikowanie różnych problemów - ze względu na zróżnicowanie przyczyn i skutków konfliktów w rodzinie - powoduje, że mediacji nie prowadzi się, gdy pomiędzy członkami rodziny występuje znaczna nierównowaga sił związana ze stosowaniem przemocy, dużą dysproporcją w dostępie do różnych zasobów lub możliwości poznawczych, gdy strony sporu mają ograniczone możliwości racjonalnego negocjowania z powodu uzależnień, zaburzeń psychicznych bądź silnych emocji, a także gdy ich oczekiwania wobec mediacji są odmienne bądź gdy w danej rodzinie występują dysfunkcyjne wzorce wzajemnego oddziaływania ${ }^{29}$. Istnieje tutaj duże niebezpieczeństwo, iż decyzje podejmowane przez członków rodziny, nawet w najlepszej wierze, nie będą mogły być przez nich dotrzymane lub podejmowane są bez pełnej świadomości zobowiązań i ich konsekwencji. W takiej sytuacji mediator może zaproponować stronom wcześniejsze, poprzedzające mediację, skorzystanie z pomocy innych specjalistów, np. prawników, terapeutów, doradców rodzinnych czy specjalistów pracy z rodziną ${ }^{30}$. Ma to

\footnotetext{
27 Ch. W. Moore, Mediacje, dz. cyt., s. 75.

28 Ch. W. Moore, Mediacje, dz. cyt., s. 82-92.

29 A. Gójska, Mediacje rodzinne, Warszawa 2014, s. 40-45.

30 Społeczna Rada do spraw Alternatywnych Metod Rozwiązywania Konfliktów i Sporów przy Ministrze Sprawiedliwości, Standardy prowadzenia mediacji i postępowania me-
} 
szczególne znaczenie m.in. w przypadku stosowania przemocy domowej. Jak wskazuje Agnieszka Rękas, taką mediację powinna poprzedzić terapia, z drugiej jednak strony autorka zwraca również uwagę na duże szanse tkwiące $\mathrm{w}$ mediacjach karnych $\mathrm{z}$ udziałem osób stosujących przemoc w rodzinie i jej doświadczających, widząc w nich narzędzie uświadomienia sprawcy krzywdy, którą wyrządził osobom bliskim, i wzięcia odpowiedzialności za swoje zachowanie ${ }^{31}$. W literaturze przedmiotu można się spotkać także ze stanowiskiem, że nawet w przypadku tak trudnych spraw, jak przemoc domowa, wykorzystanie mediacji może być niekiedy pomocne, przy czym powinno być zawsze poprzedzone diagnozą i analizą potencjalnych korzyści i zagrożeń związanych z konkretną sytuacją. Pomoc taka powinna być udzielana tylko przez doświadczonych i odpowiednio przygotowanych merytorycznie mediatorów ${ }^{32}$.

Jednym z obszarów dyskusji, który coraz częściej pojawia się w literaturze przedmiotu w kontekście mediacji rodzinnych, jest kwestia udziału w niej dziecka. Autorzy wskazują na wiele korzyści wiążących się z włączeniem dziecka do mediacji, równocześnie jednak zwracają uwagę na zagrożenia i przeciwwskazania do obecności dziecka podczas spotkania mediacyjnego $^{33}$. Agata Gójska wśród takich korzyści wymienia: wysłuchanie dziecka i poznanie jego punktu widzenia oraz potrzeb, co może być pomocne przy konstruowaniu porozumienia przez rodziców, zmniejszenie niepokojów dziecka związanych z rozstaniem rodziców, poczucie współuczestnictwa dziecka w decyzjach rodzinnych, wzmocnienie znaczenia ról rodzicielskich i wywiązywania się rodziców ze wspólnych uzgodnień, a także, o ile wymaga tego sytuacja, możliwość udzielania dziecku wczesnej pomocy przez specjalistów zaproponowanych przez mediatora. Warunkiem niezbędnym

diatora, uchwalone przez Radę w dniu 26 czerwca 2006 roku, standard VII, www.gov.pl/web/ sprawiedliwosc/miedzynarodowe-i-polskie-standardy-dotyczace-mediacji (19.05.2020).

31 A. Rękas, Przemoc w szkole i $w$ rodzinie - zastosowanie mediacji. Potencjat i realia, w: Kultura praktyki przedstawicieli profesji społecznych - podejście mediacyjne $w$ działaniu społecznym, red. E. Marynowicz-Hetka, L. Filion, D. Wolska-Prylińska, Łódź 2014, s. $268-269$.

32 A. Gójska, Mediacje rodzinne, dz. cyt., s. 179-182; A. Lewicka-Zelent, Przestrzeń dla mediacji jako formy wsparcia rodziny z problemem przemocy, w: Przemoc rodzinna. Aspekty psychologiczne, pedagogiczne i prawne, red. A. Lewicka-Zelent, Warszawa 2017, s. 177-183.

33 A. Cybulko, Mediacja w sprawach rodzinnych, w: Mediacje. Teoria i praktyka, red. E. Gmurzyńska, R. Morek, wyd. 3, Warszawa 2018, s. 341-344; A. Gójska, Mediacje rodzinne, dz. cyt., s. 206-213; A. Rękas, Przemoc w szkole i w rodzinie, dz. cyt., s. 267. 
do zaproponowania przez mediatora bezpośredniego włączenia dziecka do udziału w spotkaniu mediacyjnym jest przewidywanie mediatora, że proces rokuje pomyślnie, a w wielu kwestiach ogólnych osiągnięto już porozumienie. Wśród przeciwwskazań autorka wymienia następujące: brak zgody między rodzicami dziecka co do jego potrzeb, brak gotowości rodziców do uwzględniania potrzeb dziecka w toku negocjacji lub przeciwnie - nadmierna podatność rodziców na propozycje dziecka bez uwzględniania ich własnych potrzeb. Barierami są także niechęć rodzica do kontynuowania relacji z dzieckiem po rozwodzie, zbyt młody wiek dziecka, silny konflikt rodzicielski, w który może zostać zaangażowane dziecko oraz obawa mediatora związana $\mathrm{z}$ ewentualnym naruszeniem relacji dziecka $\mathrm{z}$ jednym $\mathrm{z}$ rodziców w sytuacji, gdy dziecko wyrazi własne preferencje w różnych kwestiach wobec drugiego z rodziców. Aby prowadzić mediacje rodzinne z udziałem dziecka, mediator musi posiadać odpowiednie przygotowanie psychologiczne i pedagogiczne oraz kompetencje do pracy $z$ dziećmi ${ }^{34}$.

$\mathrm{Na}$ koniec warto jeszcze raz zwrócić uwagę, że mediacja to forma wsparcia rodziny, w której mediator nie ma żadnej mocy decyzyjnej. Jego zadaniem jest pomoc $\mathrm{w}$ takim samym stopniu obu stronom konfliktu we wzajemnym wysłuchaniu się oraz zrozumieniu perspektywy drugiej osoby. Ogranicza się on do pomocy członkom rodziny w przezwyciężaniu barier komunikacyjnych oraz wsparciu ich przy określeniu kwestii spornych i formułowaniu propozycji rozwiązań, a także przy zawarciu obopólnie korzystnego porozumienia. Warunki tego porozumienia członkowie rodziny muszą jednak ustalić samodzielnie.

\section{Podsumowanie}

Rozwiązywanie konfliktów rodzinnych przy wsparciu mediatora pozwala na wypracowanie warunków porozumienia, które uwzględnia potrzeby i interesy wszystkich stron konfliktu. Daje tym samym szansę na trwałość ugody rodzinnej, za którą przemawia samodzielność w podjęciu decyzji i świadomość w zakresie dobrowolnie przyjętych zobowiązań. Mediacja pozwala na odejście od rywalizacyjnego sposobu rozwiązania konfliktu,

34 A. Gójska, Mediacje rodzinne, dz. cyt., s. 207-213. 
nastawionego na jednostronne zwycięstwo, na rzecz współpracy w procesie rodzinnych uzgodnień i znalezienia rozwiązania, które będzie korzystne dla wszystkich członków rodziny. Udział mediatora - osoby trzeciej, która nie jest zaangażowana w konflikt, nie ocenia, nie reprezentuje nikogo i nie przychyla się do racji żadnego członka rodziny oraz nie narzuca rozwiązania - jest szansą na konstruktywny dialog rodzinny i polubowne rozwiązanie konfliktu. Pozwala także zmienić podejście rodziny do ich konfliktu - z destruktywnego, niesprzyjającego wspólnym ustaleniom na konstruktywne, ułatwiające prace nad porozumieniem. Mediacja rodzinna zakończona zwycięstwem całej rodziny w postaci korzystnego dla wszystkich porozumienia pozwala na zachowanie relacji rodzinnych i poprawia komunikację, co daje nadzieję, że także przyszłe konflikty rodzinne mogą być rozwiązywane na drodze dialogu.

\section{Bibliografia}

Cybulko A., Komunikacja interpersonalna, w: Mediacje. Teoria i praktyka, red. E. Gmurzyńska, R. Morek, Warszawa 2009, s. 69-87.

Cybulko A., Mediacja w sprawach rodzinnych, w: Mediacje. Teoria i praktyka, red. E. Gmurzyńska, R. Morek, wyd. III, Warszawa 2018, s. 329-348.

Fisher R., Ury W., Patton B., Dochodząc do TAK. Negocjowanie bez poddawania się, tłum. R. A. Rządca, Warszawa 2013.

Gójska A., Mediacje rodzinne, Warszawa 2014.

Kalisz A., Mediacja jako forma dialogu w stosowaniu prawa, Warszawa 2016.

Lewicka-Zelent A., Przestrzeń dla mediacji jako formy wsparcia rodziny z problemem przemocy, w: Przemoc rodzinna. Aspekty psychologiczne, pedagogiczne i prawne, red. A. Lewicka-Zelent, Warszawa 2017, s. 170-184.

Ministerstwo Sprawiedliwości, Informacja o postępowaniu mediacyjnym w sprawach rodzinnych, o rozwód i separacje, www.mediacja.gov.pl/files/ doc/informacja-o-mediacji-rodzinnej.pdf (21.05.2020).

Ministerstwo Sprawiedliwości, Mediacje rodzinne $w$ latach 2006-2018 i w I pótroczu 2019 r. Postępowania w sprawach rodzinnych $w$ sądach powszechnych zakończone $w$ wyniku postępowania mediacyjnego $w$ latach 
2006-2017, isws.ms.gov.pl/pl/baza-statystyczna/opracowania-wieloletnie/ (19.05.2020).

Ministerstwo Sprawiedliwości, Mediacje rodzinne w latach 2006-2018 i w I półroczu 2019 r. Postępowanie mediacyjne w sprawach rodzinnych w sądach rejonowych w latach 2018 - I pótrocze 2019 r., www.isws.ms. gov.pl/pl/baza-statystyczna/opracowania-wieloletnie/ (19.05.2020).

Moore Ch. W., Mediacje. Praktyczne strategie rozwiązywania konfliktów, tłum. M. Zieliński, A. Cybulko, Warszawa 2009.

Rękas A., Przemoc $w$ szkole $i w$ rodzinie - zastosowanie mediacji. Potencjat i realia, w: Kultura praktyki przedstawicieli profesji społecznych - podejście mediacyjne $w$ działaniu społecznym, red. E. Marynowicz-Hetka, L. Filion, D. Wolska-Prylińska, Łódź 2014, s. 261-269.

Społeczna Rada do spraw Alternatywnych Metod Rozwiązywania Konfliktów i Sporów przy Ministrze Sprawiedliwości, Standardy prowadzenia mediacji $i$ postępowania mediatora, uchwalone przez Radę $w$ dniu 26 czerwca 2006 roku, standard VII, www.gov.pl/web/sprawiedliwosc/miedzynarodowe-i-polskie-standardy-dotyczace-mediacji (19.05.2020).

Społeczna Rada ds. Alternatywnych Metod Rozwiązywania Sporów przy Ministrze Sprawiedliwości, Rekomendacja Społecznej Rady ds. Alternatywnych Metod Rozwiązywania Sporów przy Ministrze Sprawiedliwości dotyczaca scenariusza spotkania informacyjnego na temat mediacji jako polubownej metody rozwiązywania sporów, Warszawa 28.03.2017 r., www.gov.pl/web/sprawiedliwosc/dokumenty-i-deklaracja-o-stosowaniu-mediacji (21.05.2020).

Szada-Borzyszkowska J., Mediacje w rodzinie - możliwość pokojowego rozwiązania konfliktu, w: Wyzwania współczesnego dziecinstwa i rodzicielstwa. Praca socjalna w perspektywie działań wychowawczych, red. J. Szymanowska, Toruń 2014, s. 275-288.

Szada-Borzyszkowska J., Śliwa J., Od konfliktu do porozumienia - czyli o rozwiązywaniu konfliktów droga mediacji, w: Dydaktyczna refleksja o edukacyjnych priorytetach, red. A. Karpińska, M. Zińczuk, Warszawa 2014, s. 280-291.

Ury W., Odchodzac od NIE. Negocjacje od konfrontacji do kooperacji, tłum. R. A. Robert, Warszawa 1995. 